\title{
The Rhetorical Commentary in Late Antiquity
}

\author{
Cristina Pepe \\ Università della Campania "Luigi Vanvitelli" \\ cristina.pepe@unicampania.it
}

\begin{abstract}
This paper examines the tradition of rhetorical exegesis on technical works - namely on Hermogenes' treatises - flourished from the third century AD onwards. A focus on the evidence preserved proves the exegetes' preference for the commentary format and the significant similarities in the structure and arrangement of the material with other exegetical literature of the same period. Moreover, by discussing further the content and scope of these commentaries, their relationship with teaching practice will be argued.
\end{abstract}

\section{Keywords}

Rhetorical exegesis - Hermogenes of Tarsus - Commentary - Prolegomena Neoplatonism

\section{Introduction}

The practice of textual exegesis, widespread in different areas of knowledge from philology to grammar, from philosophy to medicine, from theology to law -, also concerned rhetoric, another of the key disciplines of the ancient paideia. The activity of interpretation performed, since the Alexandrian Age, on Attic orators, first of all Demosthenes, ${ }^{1}$ was accompanied, starting from

1 This production is known to us through the double channel of the scholia, transmitted by medieval manuscripts, and of the papyri, of which the most famous is the PBerol. 9780, that preserves the exegesis of Demosthenes by Didymus; see Gibson 2002; Harding 2006; Dickey 2007, 51-55; Ucciardello 2012, 44-45. The repeated references by Didymus to the opinion of 'some' (E้vıoเ) who had preceded him (PBerol. 9780, col. 2.2-3; 7.11-14; 11.14-17; 13.16-18) show 
the III cent. $\mathrm{AD},{ }^{2}$ by a second exegetical line, focusing on 'technical' works that conveyed theoretical notions in rhetorical matter. Quite suddenly, the interpreters committed themselves to the treatises of the famous rhetorician Hermogenes of Tarsus. ${ }^{3}$

In the early 19oos, Stephan Glöckner and Hugo Rabe laid the foundations for a better knowledge of this exegetical tradition. ${ }^{4}$ After almost a century of lack of interest, studies by Michel Patillon and Malcolm Heath contributed to refocus scientific debate on these texts. ${ }^{5}$ However, many gaps are still to be filled. First of all some of these texts are still unpublished or published only partially; with a few exceptions, they remain accessible only in the volumes of the Rhetores Graeci, the monumental edition of rhetorical works realized between $183^{2}$ and 1836 by Christian Walz, which shows evident limits on the plan of textual criticism. ${ }^{6}$ Then there are some general questions requiring further investigation, such as the origins of rhetorical exegesis and the reasons that contributed to its development, the environments where it was practiced and its aims, the forms taken and methods followed, with similarities and differences compared to the exegesis performed in other areas of knowledge. ${ }^{7}$

In this paper, we will first make a review of the exegetes and their works. Then we will proceed to an analysis of the internal characteristics of the exegetical production in the period between the III and VI cent. AD. Finally, we

that he was not the first to engage in the interpretation of Demosthenes' orations and that there was a more ancient exegetical activity, to be traced back to the Alexandrians.

2 The exegesis of orators is still widespread between the II and III cent. AD. Commentaries on Demosthenes are known among the works of Zeno of Athens, Hermogenes of Tarsus and Menander of Laodicea (see Heath 2004 and infra; on the ancient exegesis of Demosthenes cf. also Lossau 1964). It is significant that among the auctores being object of this activity of interpretation there is also an exponent of the Second Sophistic such as Aelius Aristides (see in this regard the contribution of Lorenzo Miletti in this volume).

3 Hermogenes lived between the II and the III cent. AD. On his biography, full of anecdotes, see Patillon 2009, VII-XVIII.

4 Glöckner 1901 and Rabe 1895, 1899, 1908a, 1908b, 1908c, 1913, 1928; see also Kowalski 1939a, 1939b, 1940-1947.

5 Patillon, within the framework of studies on the manuscript tradition of the corpus Hermogenianum (Patillon 2008, 2009, 2012a, 2012b, 2014), has also reconsidered the circumstances of transmission of exegetical writings. Heath's works - by collecting testimonia and fragments preserved in ancient sources - have started a reconsideration of the personalities of the exegetes, especially those from an older era: see, in particular, Heath 2003a, 2003b, 2004, 2009.

6 Hereinafter the volumes of the Rhetores Graeci will be indicated with the siglum RhG.

7 Rhetorical exegesis has found little place in the studies on the development of exegesis tout court. There are no contributions dedicated to rhetorical exegesis in miscellaneous works on ancient commentary, such as Most 1999; Goulet-Cazé 2000; Geerlings-Schulze 2002 and Gibson-Shuttleworth Kraus 2002. 
will try to emphasize the connections of exegetical texts with teaching and with the didactic practices of the late antique period.

\section{The Exegetical Tradition from Late Antiquity to the Byzantine} Period

An exegetical activity on rhetoric is attested for many late antique authors. Their names and their works, known by direct tradition and/or through excerpta transmitted by later exegetes, are listed here below in order of centuries.

III cent.

- Porphyry, the Neoplatonic disciple of Plotinus, author of a commentary on

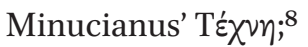

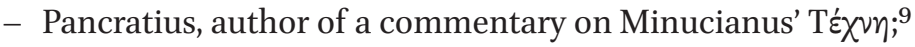

- Metrophanes, native of Eucarpia, author of a commentary on Hermogenes' T $\varepsilon ́ \chi \eta \eta$ and of a commentary on Aelius Aristides; ${ }^{10}$

- Menander of Laodicea, author of a commentary on Hermogenes and of other exegetical works. ${ }^{11}$ The interpretation of what we read in the lemma of

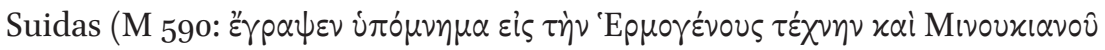
$\Pi \rho \circ \gamma \cup \mu \nu \alpha \sigma \mu \alpha \tau \alpha)$ is controversial: according to the position of the comma,

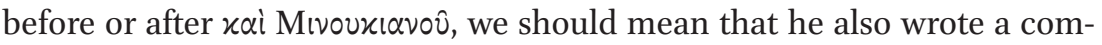

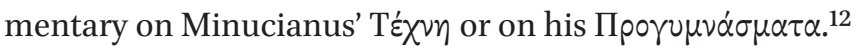

8 Suidas $\Pi$ 2098. The Teubner edition of Porphyry's work, edited by Smith 1993, does not consider most of the rhetorical fragments that have instead been collected by Heath 2003a.

9 Suidas $\Pi$ 12. On Pancratius see Heath 2004, 69, who identifies him with the father of Prohaeresius, teacher of Eunapius.

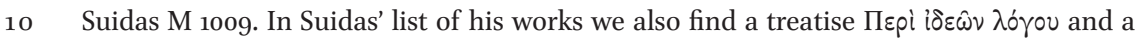

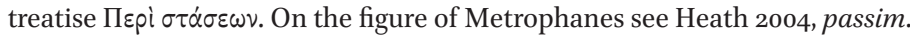

11 On the figure of Menander see, as well as Heath 2004, Russell-Wilson 1980.

12 The first interpretation is supported by Patillon 2009, vinI n. 2. The second interpretation, defended by Heath 2004, 118-119, seems to be confirmed by the syntactic arrangement of the text, with the genitive Mivouxı $\alpha v 0$ v markedly separated from the preceding

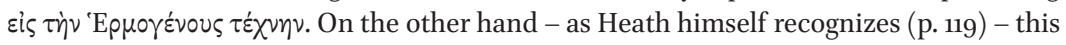
would be the only evidence of a commentary on a manual of progymnasmata which, as is known, represented the initial and more elementary stage of rhetorical education. 
IV cent.

- Evagoras, mentioned several times by Syrianus in the commentary on Пвpi $\sigma \tau \dot{\alpha} \sigma \varepsilon \omega \nu$ for his exegesis of Hermogenes; ${ }^{13}$

- Aquila, equally recalled by Syrianus but also by George and Nilus (see infra), for his interpretation of Hermogenes. ${ }^{14}$ In the opinion of most scholars, it is possible to identify this figure, qualified as 'philosopher' by Syrianus himself, with that Aquila who wrote a comment on Aristotle's Categories before $320 \mathrm{AD} ; 15$

- Sopatros, author of a commentary on Hermogenes' Пвpi $\sigma \tau \alpha \dot{\sigma} \sigma \varepsilon \omega \nu .{ }^{16}$ In addition to this commentary, other works are attributed to a rhetorician named

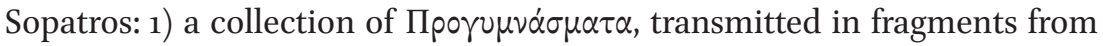
the commentaries of John of Sardis and John Doxopatres on Aphthonius'

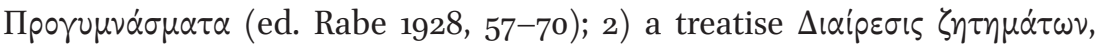
that collects eighty-two subjects of declamation, classified on the basis of the issue ( $\sigma \tau \alpha \sigma \iota \varsigma)$ they illustrate (edited in $R h G$ 8, pp. 1-385); 3) some

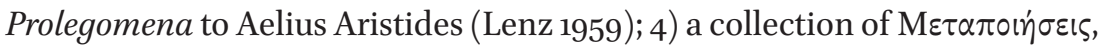
'paraphrases' of Homer and Demosthenes, equally in fragments (Glöckner 1910). The question of Sopatros' identity and the authorship of the works has been, and still is, largely debated; ${ }^{17}$

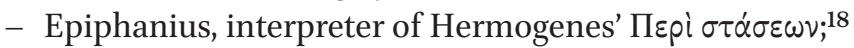

13 Usually Syrianus mentions Evagoras and Aquila together $(2.35 .2-3 ; 2.41-12.11 ; 2.55 .6$; 2.56.21; 2.60.24; 2.128.23 Rabe), while only once he refers to Evagoras alone (2.3.23 Rabe).

14 Syrianus, $2.37 .26 ; 2.39 .8 ; 2.43 .13 ; 2.50 .24$ Rabe, with the addition of references together with Evagoras.

15 Cf. Pernot 1989 and Schenkeveld 1991.

16 The commentary has been transmitted in two different versions. The first can be read in the codex Marcianus gr. Z. 433 (XI cent., edited in $R h G$ 5, pp. 1-211). The second can be found within a compilation that puts together sections of the commentaries by Syrianus, Sopatros, Marcellinus and, exceptionally, inserts extracts from Porphyry, Epiphanius, Polaemon, Athanasius. The most ancient manuscript of the compilation is the codex Parisinus gr. 2923 of $\mathrm{X}$-XI cent. (on the basis of the Parisinus and of the Aldine edition of 1509, the text was published by C. Walz in $R h G 4, \mathrm{pp} .39-846$, who generally eliminates the 'eccentric' attributions with regard to the three main authors; cf. Patillon 2008, XL-XLI). There are many other later manuscript copies, such as the Ambrosianus I 54 sup. (MartiniBassi 461) and the Parisinus gr. 2921, respectively of XV and XVI sec. On the relations between the two versions of Sopatros' commentary, that show considerable differences, there are several hypotheses: the question has recently been resumed by Maggiorini 2012, 14-20 who recalls and discusses the opinion of her predecessors.

17 See Innes-Winterbottom 1988; Heath 2004 esp. 70-71 and 295-296; Castelli 2015 and Maggiorini 2012, 9-23.

18 An extract of Epiphanius' work, as already mentioned in the footnote above, (n. 16) is preserved inside the compilation that collects Syrianus, Sopatros and Marcellinus (see $R h G 4,463.29-465.18)$. Glöckner 1901, 93-94 proposes a floruit in the middle of the IV 
- Eustathius, whose work of interpretation of Hermogenes is mentioned by later exegetes; ${ }^{19}$

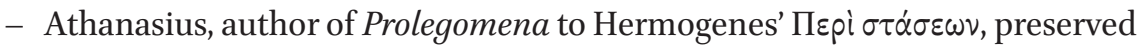
thanks to an epitome prepared by the rhetorician Zosimus. ${ }^{20}$

V-VI cent.

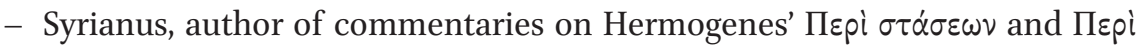

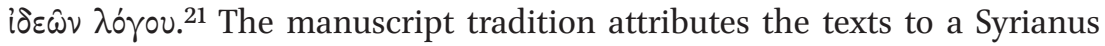
'sophist', but it is generally admitted that he is the Neoplatonic philosopher head of the school of Athens and teacher of Proclus, commentator on Homer, Plato and Aristotle, dead in $437,{ }^{22}$

- George of Alexandria (also known as George Monos), who wrote a commentary on Hermogenes' Пвpi $\sigma \tau \dot{\sigma} \sigma \varepsilon \omega \nu$, which can be dated back to the first half of the $\mathrm{v}$ cent.; ${ }^{23}$

cent. Instead, Patillon 2009, LIX, in the wake of Kennedy 1983, 137-140, opts for the second quarter of the IV cent.

19 On Eustathius see Glöckner 1901, 78-86 and Glöckner 1908-1909, 22-25; Schilling, 1903, 715-733; Rabe 1908b, 519-520; Rabe in PS, LXXI-LXXII; Heath 2004, 71.

20 The epitome is transmitted by the codex Matritensis 4687 (XV cent.), that was transcribed in Milan by Constantine Lascaris. The text is edited in PS, 171-183. On Athanasius and Zosimus see Glöckner 1901, 90-92; Schilling, 1903, 738-742; Rabe in PS, LVIII-LX; Heath 2004, 159 .

21 The two commentaries by Syrianus have been transmitted by the manuscripts Marcianus gr. Z. 433 (XI cent.) and Messina S. Salvatore 118 (XI cent.). Another, highly different, version of the commentary on Пвpi $\sigma \tau \dot{\alpha} \sigma \varepsilon \omega \nu$, has been transmitted within the compilation that also collects materials of Sopatros and Marcellinus (cf. supra n. 16). According to Heath 2004, 70 both the preserved versions of this commentary would have been summarized from a larger original, each of them preserving the material omitted in the other version.

22 See Cardullo 1987.

23 The work, of which is preserved only the part relative to the division of the $\sigma \tau \dot{\alpha} \sigma \varepsilon ı \varsigma$ (corresponding to chapters $3^{-12}$ of Hermogenes' treatise), is transmitted by three codices: the Parisinus gr. 2919 (X cent.), the Vaticanus gr. 1328 (second half of the XIII century) and the Vaticanus gr. 1298 (late $\mathrm{x}$ cent.). The Parisinus gr. 2919 contains only the comment (Hermogenes' text is quoted only occasionally). The Vaticanus gr. 1328 contains both the comment and Hermogenes' Пвpi $\sigma \tau \dot{\alpha} \sigma \varepsilon \omega \nu$. Finally, some George's passages can be read in the lower part of a quire of the codex palimpsest Vaticanus gr. 1298 (with Aelius Aristides' orations). See Arnesano 2011 and Patillon 2009, XCIV. George's name has been the object of different interpretations. The term $\mu$ óvos, read in the inscriptio of the Parisinus ( $\tau 0 \hat{0}$

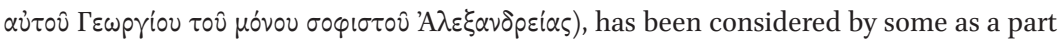
of the name of the commentator (George Monos). Others have instead considered róvos as a syncopated form of the noun rovaxós ('monk'). A third interpretation has been suggested, with convincing arguments, by Duffy 1980: póvos would be "a laudatory epithet meaning 'the one and only', in the sense of 'the great' or the like" (a similar use is attested 


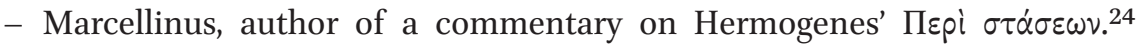
According to a generally accepted hypothesis, this Marcellinus can be identified with the homonymous author of a Life of Thucydides, who lived in the $\mathrm{V}$ cent.; ${ }^{25}$

- John of Caesarea (v cent.), who represents one of the main sources of a long

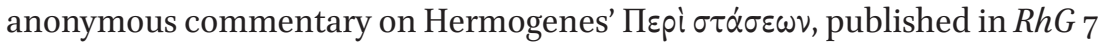
(pp. 104-696, see Heath 2003b, 15-16);

- Photius (v cent.), whose exegetical activity is known through quotations by John Doxopatres;

- Phoebammon the Egyptian (V-VI cent.), whose work of exegesis of

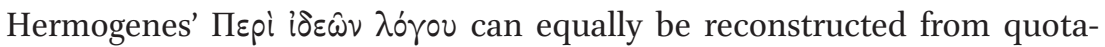
tions of later commentators. The medieval tradition has instead preserved

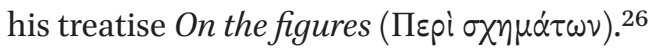

Flourishing in Late Antiquity, the activity of rhetorical exegesis is equally wellattested in the Byzantine age. In the period of the Macedonian (867-1056) and then Komnenian (XI-XII cent.) Renaissance commentaries were produced by John of Sardis, ${ }^{27}$ John the Deacon, ${ }^{28}$ Nilus, ${ }^{29}$ John Siceliotes, ${ }^{30}$ John

for $\mu \dot{\varepsilon} \gamma \alpha \varsigma$ in the comment of Olympiodorus on Plato's Gorgias). For the dating to the $\mathrm{V}$ cent. see Patillon 2009, LVIII and XCIII.

24 The commentary has been transmitted in the above-mentioned compilation that puts together materials of Sopatros and Marcellinus (see supra n. 16); in particular, for Marcellinus' commentary cf. Patillon 2009, LVIII-LIX. It is also possible to attribute to Marcellinus (entirely or only in part) the anonymous prolegomena introducing the compilation, which are edited in $P S$ 258-296, cf. Rabe in PS, LXXVI-LXXVIII; Kennedy 1994, 220-221.

25 The hypothesis, at first put forth by Oomen 1926, 74, is accepted with some doubt by Schissel 1930 and, with more conviction, by Russell 1981, 197 and Cagnetta 1986, 6o; contra Kennedy 1983, 112.

26 On Phoebammon see Rabe 1899 and Stegemann 1941. Also the work of Troilus of Side,

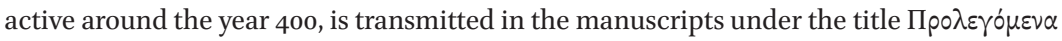

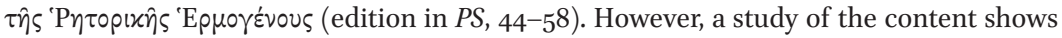
that we are rather in the presence of prolegomena to the art of rhetoric in general; see Rabe in $P S$ Xxxix.

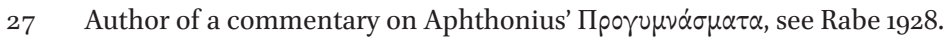

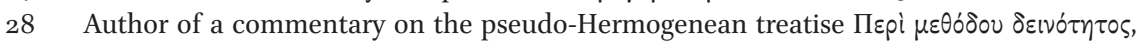
see Rabe 1908a.

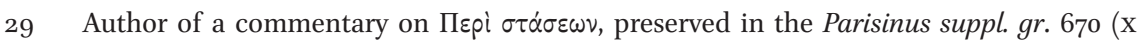
sec.). On this manuscript and on Nilus' identity, see infra n. 37 .

30 Author of a commentary on Hermogenes' Пвpi i $\delta \varepsilon \hat{\omega} \nu$, which we know through the quotations and refutations by John Doxopatres; see Romano 2007, 112 . 
Doxopatres, ${ }^{31}$ Christophorus. ${ }^{32}$ Under the Palaiologan dynasty, exegetical works were written by Maximus Planudes..$^{33}$ Anonymous works are also to be added to the list, such as the long commentary edited in $R h G 7^{34}$ Therefore, it is far from being a marginal phenomenon, considering its development for almost one thousand years in the history of the Greek culture. ${ }^{35}$ The considerable extent of the phenomenon on the diachronic plan, is also accompanied by its diffusion on the synchronic plan. In the Byzantine period, the exegetical activity was not limited to the cultural centers of the Greek East but was also developed in 'peripheral' areas such as Southern Italy. ${ }^{36}$ For a large part of the manuscripts that transmit the work of the commentators, it has been possible to reconstruct their origin in the Italo-Greek area. ${ }^{37}$ Writing of new commentaries went probably in parallel with the consultation and reuse of more ancient exegetical texts. So, the humanist Janus Lascaris reports that he had seen one of the copies of the work of George of Alexandria at the library of the scholar Sergio Stiso in Terra d'Otranto. ${ }^{38}$

An essential element resulting from this first presentation of the documented material concerns the choice of the auctor and of the texts submitted to exegesis. The most ancient exegetes, Porphyry and Pancratius show their preference for the work of Minucianus of Athens, contemporary of Hermogenes and his rival, especially for the part of rhetorical doctrine relative to the issue-theory. ${ }^{39}$ However, the situation appears completely changed in the late

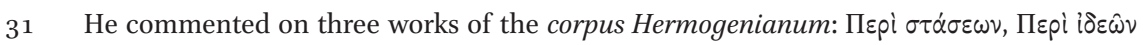

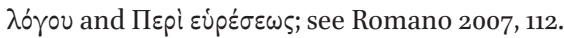

32 There is no agreement among the scholars on the Italo-Greek origin of the exegete and of the manuscript transmitting his work, Messina S. Salvatore 119, of the second half of the XII cent., see Rabe 1895 and 1908c, Romano 2007,112.

33 On the Planudes' project of edition of the corpus Hermogenianum, with prolegomena, scholia and appendixes see Patillon 2008, LXXIII-LXXV.

$34 \quad R h G_{7}$, pp. 104-696.

35 Cf. Valiavitcharska 2013, 34.

36 On the circulation of rhetorical texts in Southern Italy in the Byzantine period Irigoin 1986 and Arnesano 2011.

37 Particularly significant is the case of the codex Parisinus suppl. gr. 670, that can be dated to late $\mathrm{x}$ cent.: it contains a long commentary on Hermogenes' Пвpi $\sigma \tau \dot{\alpha} \sigma \varepsilon \omega \nu$ and is written by a person who calls himself 'Nilus monk'. He has been identified with Nilus of Rossano, founder of the Greek abbey of Grottaferrata. See Glöckner 1901; Cavallo 1980; Romano 1989, 338-339 (again in Romano 2007, 114).

38 At f. 8 or of his notebook, today Vaticanus gr. 1412, Lascaris wrote down the titles of some works owned by Stiso. The first was precisely George's commentary. Cf. Arnesano 2011, $108-111$.

39 We know Minucianus' work only through the frequent quotations by the commentators, which almost in all cases refer to problems related to the theory of the $\sigma \tau \dot{\alpha} \sigma \varepsilon ı \zeta$. These 
III century, when the activity of interpretation was entirely focused on Hermogenes. ${ }^{40}$ The reason was that Hermogenes emerged as the highest auctoritas in rhetoric, even preferred to authors like Aristotle or Dionysius of Halicarnassus, ${ }^{41}$ as also shown by the very high number of medieval codices transmitting his work. ${ }^{42}$ Under the entry 'Hermogenes' in Suidas we read that

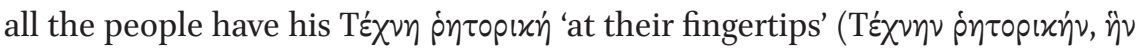

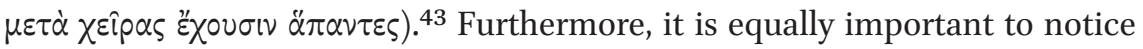
that, at least until the vi century, the efforts of the exegetes seem to focus only

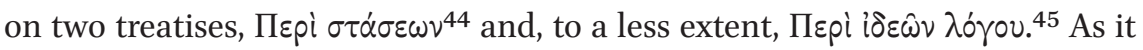
is well known, the tradition attributes to Hermogenes five writings: apart from

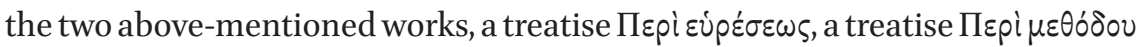

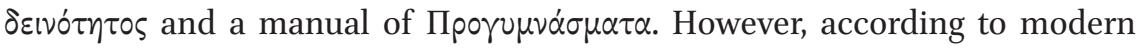
interpreters, this corpus Hermogenianum would be an artificial creation of the

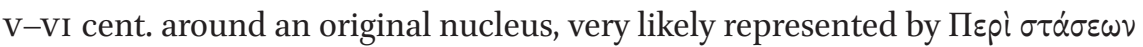

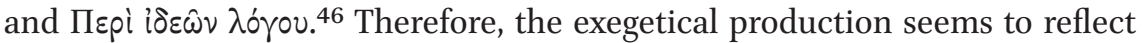

quotations also show the polemical positions expressed by Hermogenes with regard to Minucianus. See Heath 2004, 32-36.

40 We have already said that Menander, as we can read in Suidas, was engaged in the exegesis both of Hermogenes and of Minucianus. See supra $\S 2$ and n. 12.

41 In particular, it is worth noting the lack of interest for Aristotle's Rhetoric that, as well as the Poetics, seems excluded from the exegetical activity of Aristotelian and Neoplatonic commentators. The high number of manuscripts of Aristotle's works circulating between the IX and the XIV cent. do not include the Rhetoric (except for the famous Parisinus gr. 1741, of the mid-X cent., that also contains the Poetics). The first comments date back to the XII century, one written by Stephanus of Byzantium (edited in CAG 21:2,263-334) and the other, anonymous and much larger, edited in CAG 21:2,1-262. See Conley 1990; Gottschalk 1990, 68.

42 According to the estimate by Romano 2007, 107, the codices of Hermogenes and of his exegetes are about 180. A similar success was experienced, in the Latin West, by Cicero's De inventione, as witnessed once again by the important amount of medieval codices transmitting this work. A fruitful and lasting exegetical tradition, flourished around the De inventione, extends from the III cent. to the Xv cent. (see Ward 1995, 74-105).

43 Suidas E 3096. According to Patillon 2009, XVII, this information would probably be traced back to a source of the IV or V cent. AD.

44 The theory of $\sigma \tau \dot{\alpha} \sigma \varepsilon ı \varsigma$ (on which see the fundamental work by Calboli Montefusco 1986), first outlined by Hermagoras, had been at the center of the attention of rhetoricians between the II and III cent. AD. The proliferation of works aiming at explaining it seems to be a consequence of the importance that this doctrine had assumed in rhetorical education.

45 Syrianus (1.15-2-6 Rabe) claims that he had been the first to write an exegetical work on $\Pi \varepsilon p i$ i $\delta \varepsilon \omega \hat{\omega}$.

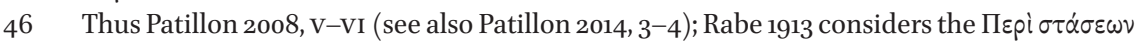

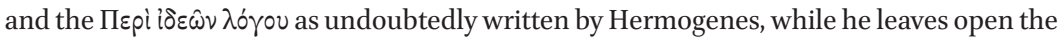

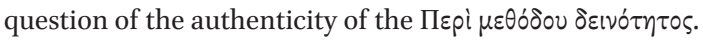


the process of formation of the corpus, initially focusing on the two works undoubtedly attributed to Hermogenes and only later paying also attention to the others, when they were already circulating under Hermogenes' name. ${ }^{47}$

Form and Structure of Exegetical Writings

For a thorough examination of the exegetical production, it is necessary to start from the observation of its characteristics from the point of view of the internal form and structure. On the formal configuration of the exegetical works only known by indirect tradition, through references or quotations by later exegetes, we cannot say very much. The title by which they are usually indicated in Suidas' Byzantine lexicon, i.e. i $\pi \dot{\mu} \mu \nu \eta \mu \alpha,{ }^{48}$ clearly evokes the form of com-

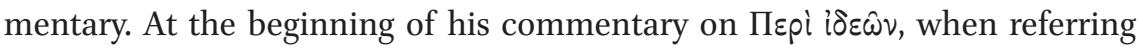
to the activity of others who, before him, had engaged in the interpretation of Hermogenes, Syrianus uses the verb $i \pi \circ \mu \nu \eta \mu \alpha \tau i \zeta \varepsilon v$ giving the impression of using it in its technical meaning of 'comment'/ 'write a commentary':

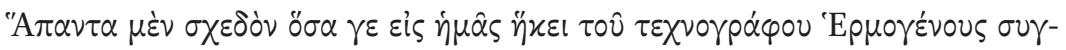

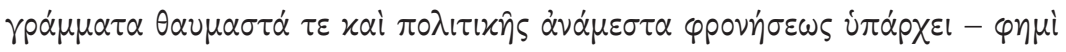

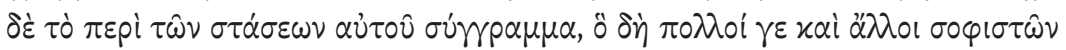

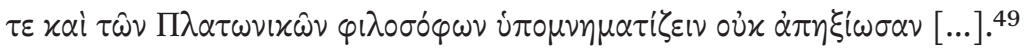

On the other hand, we cannot exclude that Hermogenean interpreters had also adopted other forms typical of exegetical literature. Syrianus himself, in the incipit of the commentary on Пвpi $\tau \tau \dot{\alpha} \sigma \varepsilon \omega \nu$, recalling again the works of those who had preceded him in the exegesis of Hermogenes, prefers to speak of $\pi \rho \alpha \gamma \mu \alpha \tau \varepsilon \hat{i} \alpha$ ('treatises'):

47 According to Patillon 2008, V-VII, the circumstances of the creation of Hermogenean corpus would be strictly related to those of formation, by an anonymous compiler, of a larger collection of rhetorical writings (corpus rhetoricum) covering in detail the different aspects of the doctrine, from the simplest (preparatory exercises) to the most complex (the stylistic doctrine). Within this corpus rhetoricum, at least until the XI cent., Aphthonius' $\Pi p \circ \gamma \nu \mu \nu \alpha \dot{\sigma} \mu \alpha \tau \alpha$ (edited by Rabe 1926) were preferred to the homonymous work attributed to Hermogenes. Aphthonius' text is object of the exegesis of John of Sardis and John Doxopatres.

48 Cf., for example, Suidas M 1009 (Metrophanes); M 590 (Menander), П 12 (Pancratius).

49 1.1.4-9 Rabe: 'Almost all the treatises by the technical writer Hermogenes that have come down to us are admirable and full of political wisdom - I refer to his treatise on the issues that many others, both sophists and Platonic philosophers, did not deem unworthy of comment' (my translation). 


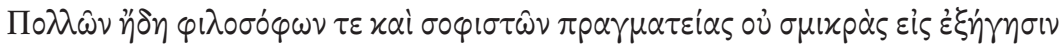

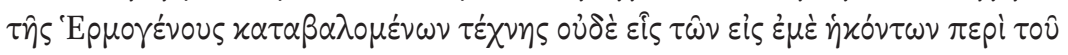

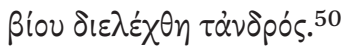

For authors like Syrianus, Sopatros, Marcellinus and George, whose work is preserved, it is possible to identify and define more precisely the internal configuration and organization of exegetical writing.

In medieval manuscripts, these texts are presented with the names of $\dot{i} \pi \circ \mu \nu \eta \dot{\mu} \mu \alpha \alpha$ or $\sigma \chi \dot{\partial} \lambda \iota \alpha$. Some examples come from the codices Marcianus gr. Z. 433 and Parisinus gr. 2919, which transmit respectively the works of Syrianus and Sopatros and George's work:

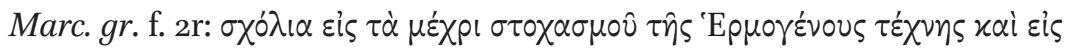

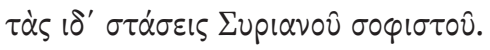

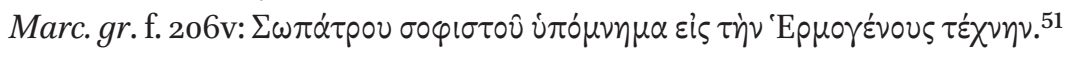

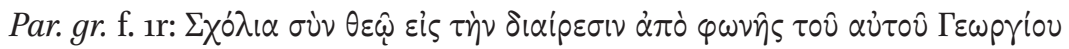

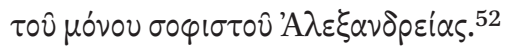

A study of Sopatros' work, transmitted by the codex Marcianus, allows to qualify it as a commentary in the strict sense, since it satisfies the two characteristics recognized as distinctive of this genre: the nature of second-order discourse, ${ }^{53}$ aiming at explaining and interpreting another text on which it depends, and the structure by lemmata which reproduce a more or less extended part of the text on which is performed the exegesis. ${ }^{54}$ More precisely, it is a 'continuous commentary', because the basic text is commented in extenso. ${ }^{55}$

Of the two exegetical works by Syrianus, we can consider as a continuous commentary the text on Пвpi i $\delta \varepsilon \omega \hat{\nu}$, even though the exegesis does not cover the whole Hermogenes' treatise but is interrupted at the ninth chapter of the

50 2.1.6-9 Rabe: 'Among the numerous philosophers and sophists who have composed not short treatises to explain Hermogenes' art, no one of those which have come down to me has spoken of the life of that man' (my translation).

$5^{1}$ The term $\tau \varepsilon \chi \chi \eta ~ i s ~ u s e d ~ h e r e ~ t o ~ i n d i c a t e ~ t h e ~ П \varepsilon p i ~ \sigma \tau \alpha \dot{\sigma \varepsilon \varepsilon \omega \nu ; ~ c f . ~ t h e ~ s i m i l a r ~ u s a g e ~ i n ~ S u i d a s ~}$ M 590 and M 1009 .

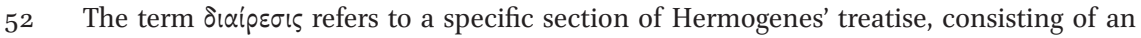
introduction, a chapter on method ( $\mu \varepsilon \theta_{0} \circ \delta \circ \varsigma$ ) and, precisely, a broad discussion about the

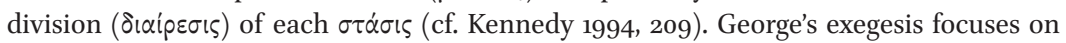
this last section, cf. what said supra n. 23 .

53 'Second-order discourse' is the expression used by Baltussen 2007, 254.

54 For a definition of commentary, see Del Fabbro 1979, 69 followed by Abbamonte 1994, 220-221 and Dorandi 2000, 15. Cf. also Romano 1994, 599.

55 Dorandi 2000, 15 . 
second book, without considering the last three. Syrianus explains the interruption by affirming that the final part of Hermogenes' text - the discussion about political discourses (deliberative, judicial and epideictic), writers of dialogues and historiographers - appears perfectly clear and can be understood by those who have thoroughly studied all of the above. ${ }^{56}$

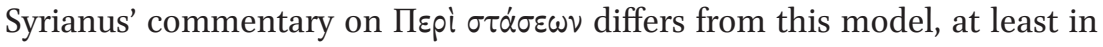
the version transmitted by the codex Marcianus. It has a structure by lemmata only in the initial part, which comments the first chapter and the beginning of the second chapter of Hermogenes' treatise. In the following part, the work leaves the form of commentary and takes on that of a monograph, organized in fourteen sections, each containing an exposition of every issue. ${ }^{57}$ Syrianus himself programmatically announces and justifies this change of direction. Until that moment, he explains, he had followed Hermogenes' exposition be-

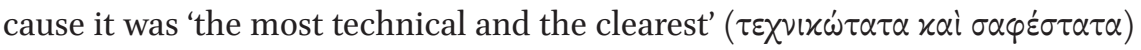

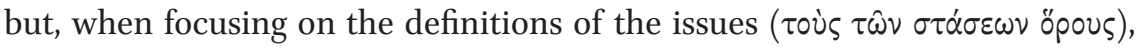

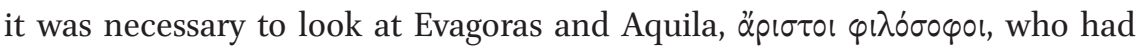

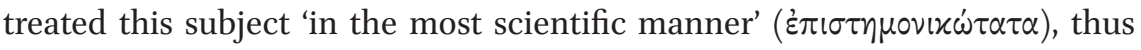

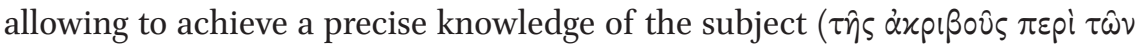
$\left.\sigma \tau \dot{\alpha} \sigma \varepsilon \omega \nu \gamma \gamma \omega^{\prime} \sigma \varepsilon \omega \varsigma\right) .{ }^{58}$ Therefore, the abandonment of the hypomnematic form coincides with the choice of two new auctoritates, Evagoras and Aquila.

$5^{6} \quad 1.95 \cdot 5^{-9}$ Rabe. It is useful to recall that a tendency to reduction, towards the end of the text being commented, is shared by ancient commentaries, also in contexts other than rhetoric; see in this regard Nünlist 2009, 12.

57 For every $\sigma \tau \dot{\alpha} \sigma \iota \varsigma$, Syrianus analyzes the definitions (öpol) and the internal divisions

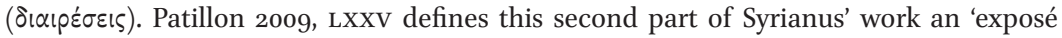
doctrinal'.

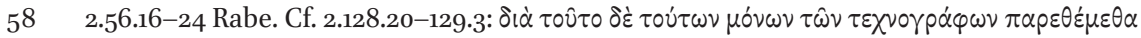

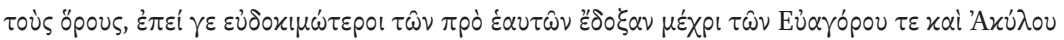

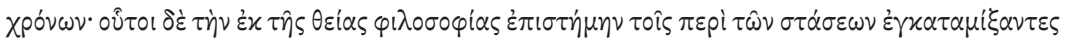

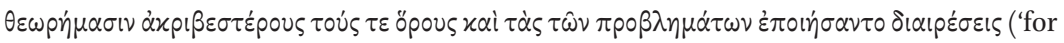
this, we have reported only the definitions of these technical writers, because they were more reputed among our predecessors, until the times of Evagoras and Aquila; but the latter, having combined the issue-theory with the science deriving from divine philosophy, have created more precise definitions and divisions of the questions'; my translation). 
A particular case is that of the compilation putting together materials of Marcellinus, Sopatros and Syrianus. ${ }^{59}$ This is in fact a sort of 'multiple' commentary, collecting around each lemma the comments of several exegetes. ${ }^{60}$

Finally, George's commentary is highly interesting because of its particular internal configuration. It is organized in $54 \pi \rho \dot{\alpha} \xi \varepsilon ı$ ('lectures'), sequentially numbered (alpha, beta, gamma, etc.) and of unequal length, that clarify various sections of Hermogenes' treatise. Each $\pi p \alpha \hat{\xi} ı \zeta$ is then divided in a series of chapters $(\varkappa \varepsilon \varphi \alpha \dot{\lambda} \lambda \alpha \alpha) .{ }^{61}$ This organization in $\pi \rho \alpha \dot{\xi \varepsilon \varepsilon \zeta ~ s h o w s ~ a ~ s i g n i f i c a n t ~ a n a l o g y ~}$ with that of some Neoplatonic commentaries. ${ }^{62}$ Also the formula we read in

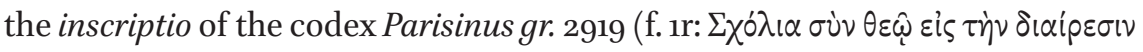

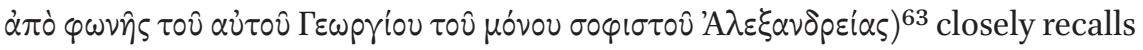
those that we find in the manuscripts of Neoplatonic commentaries. ${ }^{64}$ This

59 See supra n. 16. According to Patillon 2009, LIX (see also Patillon 2008, XLI) the original nucleus of the compilation, in which it is possible to recognize several changes and a lot of glosses, would be traced back to Late Antiquity and could be dated to the second half of the V cent. or to early VI cent. Same opinion in Maggiorini 2012, 16-18 who, independently from Patillon (whose works are not mentioned), goes as far as supposing that the final compiler was Marcellinus. Contra Heath 2004, 70-71, who thinks that the grouping took place by an unknown Byzantine scholar much later than the redaction of the three commentaries.

6o In the codex Parisinus, the commentary is full page with more or less long sequences of Hermogenes' text in a centered position, which separate the different exegetical sections, while in the margin there are, in an abbreviated form, the names of the commentators. On the tradition of multiple commentaries, see the contribution of Giancarlo Abbamonte in this volume.

61 As already said, the Vaticanus gr. 1328 contains both the commentary and the text of Пвpi $\sigma \tau \dot{\alpha} \sigma \varepsilon \omega \nu$ : in it, integral quotations of Hermogenes' text (defined with the expression $\tau \dot{0}$

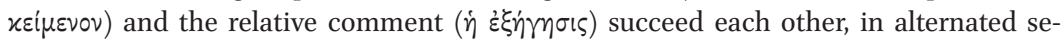
quences. In the Parisinus gr. 2919, containing only the commentary, the quotations of Hermogenes' text usually appear at the beginning of the $\pi \rho \hat{\alpha} \xi ı$, but they can also be inserted during the exposition, sometimes with slight modifications to ensure the grammatical and logical continuity with the latter. Instead, in George's extracts contained in the Vaticanus gr. 1298 there are no Hermogenes' quotations. Cf. Patillon 2009, LXIII, LXXXVIII-LXXXIX, XCIV.

62 In the Neoplatonic commentaries, each $\pi \rho \hat{\alpha} \xi ı$ is usually divided in $\theta \varepsilon \omega \rho \dot{i} \alpha$ (i.e. explanation and interpretation of the content, of the doctrine), and $\lambda \varepsilon^{\xi} \xi$ เ (i.e. explanation of individual words or sentences), see Lamberz 1987, Hadot 1997, 170 and Szabat 2015, 259-260. It is widely believed that such a structure was already used in Middle Platonic commentaries (Dörrie-Baltes 1993, 169-170; Mansfeld 1994, 161-163; Ferrari 2001, 566-570); contra Petrucci 2017.

63 The formula is also reported, though with slight modifications (see Arnesano 2011, 110), in the annotation by Janus Lascaris (Vaticanus gr. 1412, f. 8or), cf. supra n. 38.

64 Cf., for ex., the formula opening the commentary on Aristotle's Metaphysics, transmit-

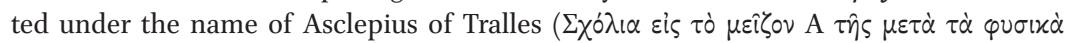

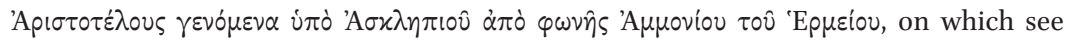


formula sheds light on the nature and on the particular modalities of compilation of the work: these are 'notes' $(\sigma \chi \dot{\partial} \lambda \iota \alpha)$ drawn up $\alpha \dot{\pi} \dot{o} \varphi \omega \nu \eta \hat{\varsigma} s$, 'from the voice' of George, that is to say, on the basis of his oral teaching. ${ }^{65}$ The subscriptio present in the same codex would also seem to identify the author of the more or less faithful transcription of George's lectures: his disciple Zeno (f. 245v:

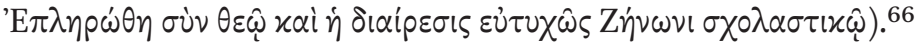

Another element contributes to characterize - both on the formal plan and in terms of content - the exegetical production in the rhetorical context: the presence of prolegomena, introductory sections containing preliminary questions for the study of Hermogenes' treatises or of rhetoric in general. ${ }^{67}$ These prolegomena were initially an integral part of the commentaries, as is the case for the works of Sopatros ${ }^{68}$ and Syrianus; ${ }^{69}$ however, it is possible that they had already begun to be produced as autonomous texts in the ancient period. ${ }^{70}$ The prolegomena to rhetoric follow three different schemes: the first consists in examining fundamental notions, such as the definition of discourse, the distinction between the two arts of the discourse (grammar and rhetoric), the tasks of an orator; the second and third models discuss instead a series of questions, either in a simpler or a more complex form. ${ }^{71}$ In the first case, four

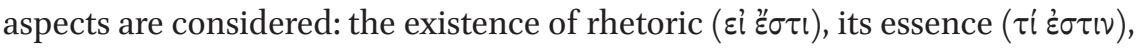

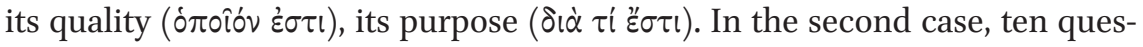
tions or points ( $\varkappa \varepsilon \varphi \alpha \dot{\lambda} \lambda\llcorner\alpha)$ are addressed: 1$)$ the existence of rhetoric among the gods; 2 ) the existence of rhetoric among the heroes; 3 ) its arrival among men; 4) its apogee in Athens; 5) its definition, aims and tasks; 6) its genres and their origin in the parts of the soul; 7 ) the different types of rhetoric (philosophical,

Cardullo 2012), or that introducing the commentary on Plato's Gorgias by Olympiodorus

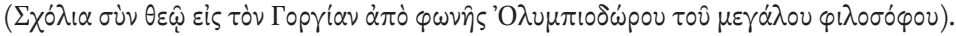

65 A fundamental work for the interpretation of these formulas and, in particular, of the expression $\dot{\alpha} \pi \dot{\partial} \varphi \omega \nu \eta \hat{s}$, is that of Richard 1950 .

66 This is how the expression Zñ $\omega \nu$ เ $\sigma \times 0 \lambda \alpha \sigma \tau i x \hat{\omega}$ is understood both by Schilling 1903, 667 and by Richard 1950, 204.

67 The prolegomena, many of which anonymous, were collected for the first time in a single volume by H. Rabe (Prolegomenon Sylloge, here shortened to PS). Cf. also Rabe 19o9; Kennedy 1983, 116-122; Patillon 2008, 3 ff.; Patillon 2012b, 2-10; Calboli Montefusco 2010.

68 See $R h G$ 5.1.1-3.17.

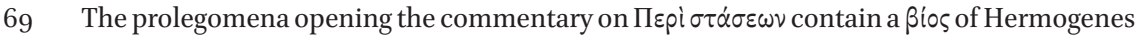
(2.1.9-3.7 Rabe). The prolegomena by which Syrianus opens the commentary on Пвpi $i \delta \varepsilon \omega \hat{\nu}$ are preserved in two different versions, of which the broadest is transmitted in medieval manuscripts independently from the commentary (on the question see Rabe 1892-1893, vol. I, pp. VI-X).

70 In medieval manuscripts, they are usually placed prior to the text of Hermogenes' treatises.

71 Rabe 1909 (=PS, III-VI), Patillon 2008, 3-6. 
political, dialectic, etc.); 8) the modalities of rhetorical reading; 9) the different political systems; 10) the ways to explain rhetoric. The prolegomena to each treatise, together with general considerations on rhetoric, explain some particular characteristics of the treatise. ${ }^{72}$ There are evident similarities between these schemata isagogica and those attested for other disciplines, from grammar (and literary criticism) to philosophy, from medicine to theology. ${ }^{73}$

There are several signs that can allow recognizing a deep relation between the production of exegetical writings and the coeval practices for the teaching of rhetoric.

A first clue is the almost immediate and lasting success of Hermogenes as auctor on which is performed the exegesis. The extraordinary fortune enjoyed by the work of the rhetorician of Tarsus in Late Antiquity and then in the Byzantine period induces to think that it had become the work of reference in school education. Since Hermogenes' treatises were included in the educational curriculum of the students, it can be assumed that the comments were conceived as teaching tools designed to facilitate learning ${ }^{74}$ : we can imagine that the reading, during lectures, of sections of Hermogenes' work was followed

$72 \quad P S$, VI-VII; cf. Van Berchem 1952, 80-81; Mansfeld 1994, 52.

73 Rabe 1931, v supposed that the rhetorical prolegomena were modelled on those of the Neoplatonic commentators on Plato's and Aristotle's works (on this, see Hoffmann 2006, 607-614); same opinion by Kennedy 1994, 218. A derivation in the opposite sense, with the philosophical prolegomena influenced by the rhetorical ones, is instead suggested by Patillon 2008, 5-6. In fact, Mansfeld 1994, 53 ff. has the merit of pointing out that these schemes or sections of isagogical character were shared, in Late Antiquity, by several disciplines (before him Van Berchem 1952, esp. 81). For some of them it has been possible to recognize that they depended on the most ancient exegetical tradition, that of the Alexandrian age, while it is highly complex to make a more general discussion on the derivations and transitions from one discipline to another. Also helpful Stok 2018, who focuses on the schemata isagogica in Virgilian exegesis.

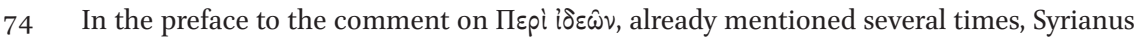
(1.2.4-7 Rabe) identifies, by an apostrophe, the person to whom his work is addressed:

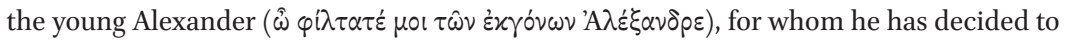
put together the short notes gathered in view of a more accurate reading of Hermogenes'

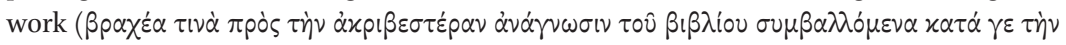

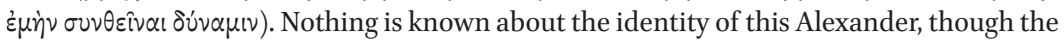
term हैx yovos would seem to suggest a parent-child, or at least family, relationship with Syrianus. Anyway, what is important for our purposes is that the commentary is based on notes, with a clear catechetical function. 
by the teacher's comment; the material used orally, reorganized and put in writing, was then published on the initiative of the teacher himself or of one of his pupils. ${ }^{75}$ This scenario is clearly suggested by a work like that of George where the $\pi \rho \dot{\alpha} \xi \varepsilon ı \zeta$ that mark the written commentary appear as the reflection of the organization of the oral course in a series of didactic units. ${ }^{76}$

The habit of placing isagogical schemes, like the prolegomena, prior to the comment also meets a purely didactic purpose.

An important confirmation of the pedagogical matrix of the commentaries seems to come from the observation of the exegetical strategies used. It is an essential aspect on which, as stressed at the beginning, there are no systematic enquiries so far. Nonetheless, even a cursory glance allows to notice a preference for strategies aiming at facilitating the comprehension of the text, such as gloss, differentiae verborum, paraphrases, exemplification ${ }^{77}$ while, for instance, purely philological annotations, less appropriate in a teaching context, are less frequent. ${ }^{78}$

Finally, the frequent use, by commentators, of compilatory and doxographical method fits well within this representation: for those who write a didactic commentary, reporting the different opinions of the predecessors and drawing on preexisting materials is necessary or even inevitable. ${ }^{79}$ In this regard, Pierluigi Donini's words are illuminating:

Dovremmo forse pensare alla nostra stessa esperienza di scrittori di manuali scolastici o di saggi di divulgazione: è in principio escluso che siano queste le forme letterarie in cui riveliamo tutta quanta l'originalità di cui siamo capaci. La materia da esporre è infatti quella e lo schema espositivo

75 Numerous ancient sources illustrate the students' practice to take notes during lectures and, in some cases, to put them into circulation (some examples gathered and discussed by Heath 2004, $261 \mathrm{ff}$.). One of the most interesting testimonies for our discussion is that of Marinus, Proclus' biographer (Life of Proclus 12), who tells that the Neoplatonist Plutarch had encouraged Proclus to take notes $\left(\sigma \chi \delta^{\prime} \lambda l \alpha\right)$ of his classes on Phaedon, with the aim to publish in the future commentaries (i $\pi \circ \mu \nu \dot{\eta} \mu \alpha \tau \alpha)$ under Proclus' own name.

76 With regard to Neoplatonic philosophical commentaries Szabat 2015, 259-26o emphasizes that they are influenced, in their structure and form, by the original oral form, which also explains the presence of references to previous lessons, repetitions, insertion of direct discourse, questions put by the teacher to his pupils.

77 I am only showing here an example for each typology, taken from Syrianus' work: 1.39.1115 Rabe (gloss); 2.192.1-14 Rabe (differentia verborum); 1.40.12-15 Rabe (paraphrase); 1.26.19-27.4 Rabe (exemplification).

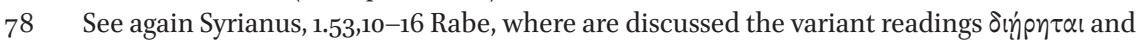
$\delta เ \bar{p} \tau \alpha \iota$.

Donini 1994, 5059; Sluiter 1999, 173. 
è, di solito, quasi obbligato: si pensi agli indici e alla partizione in capitoli delle nostre moderne storie della filosofia o di qualsiasi manuale di una disciplina scientificamente costituita da tempo - sono quasi completamente eguali in tutte le opere. ${ }^{80}$

Recalling the predecessors, which gives the commentators the possibility to place themselves and their own work within a certain exegetical tradition, ${ }^{81}$ does not imply, on the other hand, renouncing their autonomous assessments and some search for originality. Commentators, at least in the earlier phases, do not fail to distance themselves both from Hermogenes' text ${ }^{82}$ and from the opinions expressed by previous exegetes or to intervene by additions, omissions and variations, thus showing their own way of looking at things and going as far as to take the interpretation of a well-established doctrine as the starting point for personal contributions of theoretical nature. ${ }^{83}$ On the other hand, it does not seem possible to ascribe to chance the fact that, in our documentation, the diffusion of commentaries coincides with the gradual exhaustion of the production of Technai: the exegetical writings, created to accompany and exemplify the reading of Hermogenes, ended up including all the speculation and creative reflection in rhetoric. ${ }^{84}$

Recognizing that rhetorical commentaries are the result or the tool of teaching, or both at once, gives rise to a series of new questions about the profile of those who engaged in exegetical activity, the environments where they operated, the levels of teaching for which the commentaries were conceived, the age of the students for whom they were intended. As one can easily imagine, the answer to these questions is complex and not unique. ${ }^{85}$ However, there is

\footnotetext{
8o Donini 1994, 5059.

81 Rogers 2017, 49.

82 The clear refusal of Hermogenes' exposition by Syrianus in favor of that of Aquila and Evagoras (supra $\S 3$ and n. 58 ) represents one of the most significant examples of the critical attitude of the commentators.

83 Heath 2003a, 165-166; Heath 2004, 73. The importance of the innovative contribution varies from a commentary to the other, cf. the comparative analysis of those of Syrianus, Sopatros and George offered by Patillon 2009, LXXIV-LXXXVI. Anyway, it is worth emphasizing the difficulty, for modern scholars, to exactly distinguish personal interventions and innovations by each author: rhetorical commentaries are, by their own nature, fluid and dynamic texts, characterized by weak authorship and open to glosses, supplements, epitomes and contaminations.

84 Cf. Heath 2003a, 165-166.

85 There are some considerations on these aspects in Heath 2004, $217 \mathrm{ff}$. The discussion on the commentaries on Hermogenes has found little place in the most important studies on education and teaching of rhetoric in Late Antiquity, as Cribiore 2007 and 2013; Watts 2008.
} 
at least one aspect on which it is worth making a reflection at the end of this work. Among the commentators of Late Antiquity, there are first of all professional rhetoricians like Pancratius and Menander, usually qualified with the term $\sigma 0 \varphi 1 \sigma \tau \alpha i^{8}{ }^{86}$ However, a careful analysis of the sources induces to think that the exposition and explanation of Hermogenes' works was not an exclusive prerogative of the rhetoricians. Syrianus, placing the redaction of his commentaries within the framework of a well-established practice, mentions two categories of predecessors: not only the 'sophists' but also the 'philosophers'

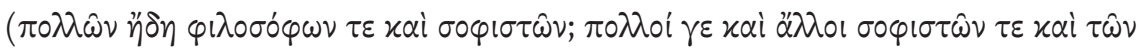

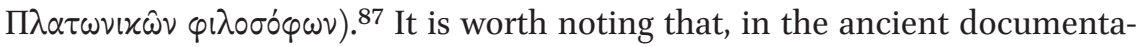
tion, it is not always easy to draw the boundaries between the figures of rhetoricians-sophists and philosophers. ${ }^{88}$ So, for instance Suidas' lexicon describes Tiberius both as 'philosopher' and as 'sophist'; 89 a Harpocration is celebrated as 'rhetorician' and 'philosopher' in an Athenian funerary inscription of the III cent. AD. ${ }^{90}$ The biographical tradition often presents cases of authors who went through teaching of rhetoric before arriving at teaching philosophy, but also of authors who continued to teach both disciplines all of the time. ${ }^{91}$ On the other hand, the statements by Syrianus, who apparently wants to make a clear distinction between the two groups, seem to leave no doubt as to the fact that Hermogenes' exegesis was also practiced, and rather commonly, by philosophers, in particular by 'Platonic' philosophers. ${ }^{92}$ Therefore, we should not be surprised of the fact that the first in the list of commentators is a key figure in the history of Neoplatonism like Porphyry. ${ }^{93}$ It is possible to find a connection with Neoplatonic circles, in a more or less evident manner, for other exegetes,

86 See the lemmata Menander and Pancratius in Suidas (M 590, П 12); Sopatros and George

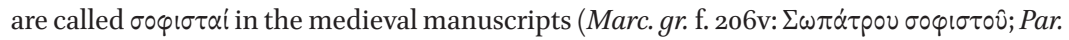

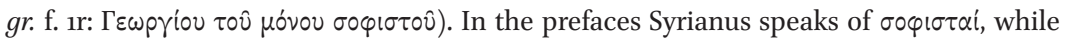
elsewhere (for ex. 2.128.20 Rabe) he prefers the word $\tau \varepsilon \chi \nu 0 \gamma p \alpha ́ \varphi 0 l$.

$87 \quad$ 1.1.8 and 2.1.6 Rabe, cf. supra $\S 3$ and nn. 49-50.

88 On the oscillations see Heath 2009, 144-146.

89 Suidas T $55^{\circ}$.

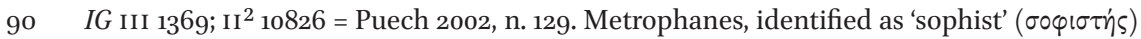
in Suidas, is mentioned by Syrianus (2.55.5 Rabe) with the title 'Platonic' ( $\delta \Pi \lambda \alpha \tau \omega \nu$ ixós).

91 See Heath 2009, 148-149.

92 The use, repeated in two passages, of the adjective $\pi \circ \lambda$ of is indicative of a common practice.

93 Eunapius insists on Porphyry's polymathia, expressing some doubts as to whether his most significant contribution had been given in rhetoric, literary criticism, arithmetic, geometry or in the various branches of philosophy (Lives of the Sophists $4.2 .2-3=9.11-19$ Giangrande). 
starting from Syrianus himself. ${ }^{94}$ It is necessary to take into account such observations not only in the studies on the addressees, on the functions and use of commentaries, but also, in a broader perspective, in any enquiry aiming at reconstructing the role played by rhetoric and its relationship with philosophy in the late antique school system.

\section{Acknowledgements}

I am grateful to Giancarlo Abbamonte, Lorenzo Miletti, Federico Maria Petrucci and Luigi Spina who read the text and enriched it with their remarks.

\section{Bibliography}

Abbamonte, G. (1994). Il primo libro del commento di Alessandro di Afrodisia. In: Aristotelis Topica. Saggio introduttivo, testo, traduzione e note, 3 voll., Salerno (Tesi di dottorato inedita).

Arnesano, D. (2011). Ermogene e la cerchia erudita. Manoscritti di contenuto retorico in Terra d'Otranto. In: N. Bianchi (ed.), La tradizione dei testi greci in Italia meridionale. Filagato da Cerami philosophos e didaskalos. Copisti, lettori, eruditi in Puglia tra XII eXVI secolo (Biblioteca tardoantica 5), Bari, pp. 95-111.

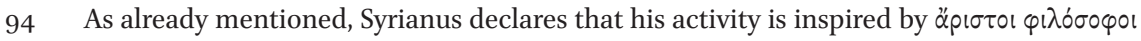
like Aquila and Evagoras (2.56.16-24; 2.128.20-129.3 Rabe, discussed supra). In his two commentaries, there are frequent quotations of Plato, qualified by Syrianus with the epithet 'divine' ( $\theta \varepsilon \hat{\varepsilon} 0$ ૬); cf. for ex. 2.173.24 and 180.14 Rabe. These elements confirm the hypothesis of identification with the philosopher head of the Neoplatonic school of Athens (see supra § 3). It is possible to find Neoplatonic influences also in the works of Sopatros and Marcellinus (fundamental on this, the pages of Kennedy 1983, 52-53, 73-86 and Kennedy 1994, 209 ff.; recently Maggiorini 2012, esp. 38, 58, 62, has pointed out the relation between biographical data and rhetorical system of Sopatros, on the one hand, and Athenian Neoplatonism on the other hand). The attention of Neoplatonists to rhetoric, also shown by the production of commentaries to dialogues such as Gorgias and Phaedrus, is recognized by Hadot 1990, 300-301. In her important volume Arts libéraux et philosophie dans la pensée antique published in 1984 (a revised and expanded edition appeared in 2005), Hadot herself has enlightened the gradual re-evaluation of rhetoric in the long Platonic tradition, a re-evaluation that led to recognize it as an integral part of philosophical education. Sorabji 1990, 9-10 supposes that courses of rhetoric were held in the Neoplatonic schools of Apamea and Alexandria. In particular, the study of Hermogenes' texts was for the philosophers a "training in logical method" (Kennedy 1994, 209). For the contribution given by Neoplatonists to the discussion on the genres of rhetoric see Pepe 2013, 259-260, 284, 324 n. 188. 
Baltussen, H. (2007). From Polemic to Exegesis:The Ancient Philosophical Commentary. Poetics Today 28, pp. 247-281.

CAG - Commentaria in Aristotelem Graeca, 23 voll. Berlin 1882-1909.

Cagnetta, M. (1986). Per una edizione critica della Vita di Tucidide di Marcellino. BollClass s. III, 7, pp. 59-80.

Calboli Montefusco, L. (1986). La dottrina degli status nella retorica greca e romana. Hildesheim.

Calboli Montefusco, L. (2010). Do you know enough about rhetoric? In: L. Brisson, P. Chiron (édd.), Rhetorica philosophans. Mélanges en l'honneur de M. Patillon, Paris, pp. $239-256$.

Cardullo, L. (1987). Siriano nella storiografia filosofica moderna e contemporanea. SicGymn n.s. XL 1-2, pp. 71-182.

Cardullo, L., ed. (2012). Asclepio di Tralle, Commentario al libro "Alpha meizon" (A) della "Metafisica" di Aristotele, Introduzione, testo greco, traduzione e note di commento. Acireale-Roma.

Castelli, C. (2015). Sopater [2]. In: F. Montanari, F. Montana e L. Pagani (eds.), Lexicon of Greek Grammarians of Antiquity, Consulted online on 15 November $2018<\mathrm{http}$ :/ dx.doi.org/10.1163/2451-9278_Sopater_2>. First published online: 2015 .

Cavallo, G. (1980). La trasmissione scritta della cultura greca antica in Calabria e in Sicilia tra i secoli X-XV. Scrittura e Civiltà 4, pp. 157-245.

Conley, T. (1990). Aristotle's Rhetoric in Byzantium. Rhetorica 8, pp. 29-44.

Cribiore, R. (2007). The School of Libanius in Late Antique Antioch. Princeton.

Cribiore, R. (2013). Libanius the Sophist: Rhetoric, Reality, and Religion in the Fourth Century. (Townsend lectures/Cornell studies in classical philology). Ithaca-London.

Del Fabbro, M. (1979). Il commentario nella tradizione papiracea. StudPap 18, pp. 69-132.

Dickey, E. (2007). Ancient Greek Scholarship. Oxford.

Donini, P. (1994). Testi e commenti, manuali e insegnamento: la forma sistematica e $i$ metodi della filosofia in età postellenistica. In: ANRW II, 36.7, pp. 5027-5100 (= Donini 2011, pp. 211-281).

Donini, P. (2011). Commentary and tradition: Aristotelianism, Platonism, and post-Hellenistic philosophy, ed. by Mauro Bonazzi (Commentaria in Aristotelem Graeca et Byzantina. Quellen und Studien 4). Berlin-New York.

Dorandi, T. (2000). Le commentaire dans la tradition papyrologique: quelques cas controversés. In: Goulet-Cazé 2000, pp. 15-27.

Dörrie, H. und Baltes, M. (1993). Der Platonismus in der Antike. Band III:Der Platonismus im 2. und 3. Jahrhundert nach Christus. Stuttgart-Bad Cannstatt.

Duffy, J. (1980). Philologica Byzantina. G RBS 21, pp. 261-268.

Ferrari, F. (2001). La funzione dell'esegesi testuale nel medioplatonismo: il caso del Timeo. Athenaeum 89, pp. 525-574. 
Geerlings, W. und Schulze, C. (2002). Der Kommentar in Antike und Mittelalter. Beitrage zu seiner Erforschung (Clavis Commentariorum Antiquitatis et Medii Aevi 2). Leiden.

Giangrande, I. (1956). Eunapii Vitae sophistarum. Roma.

Gibson, C. A. (2002). Interpreting a Classic: Demosthenes and his Ancient Commentators. Berkeley (CA).

Gibson, R. K. and Shuttleworth Kraus, C., eds. (2002). The Classical Commentary. History, Practices, Theory (Mnemosyne Supplement 232). Leiden.

Glöckner, St. (1901). Quaestiones rhetoricae. Historiae artis rhetoricae qualis fuerit aevo imperatorio capita selecta (Breslauer Philologische Abhandlungen 8.2). Breslau.

Glöckner, St. (1908-1909). Über den Kommentar des Johannes Doxopatres zu den Staseis des Hermogenes, 2 voll. Kirchhain.

Glöckner, St. (1910). Aus Sopatros MЕТАПОІЕ $\Sigma$ ЕІ $\Sigma$. RhM 65, pp. 504-414.

Gottschalk, N. (1990). The earliest Aristotelian commentators. In: Sorabji 1990, pp. $55^{-81 .}$

Goulet-Cazé, M. O. ed. (2000). Le commentaire entre tradition et innovation. Actes du colloque international de l'Institut des traditions textuelles (Paris et Villejuif, 22-25 septembre 1999), Paris.

Hadot, I. (1990). The life and work of Simplicius in Greek and Arabic sources. In: Sorabji 1990, pp. 275-303.

Hadot, I. (1997). Le commentaire philosophique continu dans l'Antiquité. AntTard 5 , pp. $169-176$.

Hadot, I. (2005). Arts libéraux et philosophie dans la pensée antique: contribution à l'histoire de l'éducation et de la culture dans l'antiquité. Seconde édition revue et considérablement augmentée. Paris.

Harding, P. (2006). Didymos: On Demosthenes. Oxford.

Heath, M. (2003a). Porphyry's rhetoric. CQ 53/1, pp. 141-166.

Heath, M. (2003b). Metalepsis, paragraphe and the scholia to Hermogenes. Leeds International Classical Studies 2/2, pp. 1-91.

Heath, M. (2004). Menander: A Rhetor in Context. Oxford.

Heath, M. (2009). Platonists and the teaching of rhetoric in late antiquity. In: P. Vassilopoulou, S.R.L. Clark (eds.), Late Antique Epistemology: other ways to truth, London, pp. 143-159.

Hoffmann, P. (2006). What was Commentary in Late Antiquity? The Example of the Neoplatonic Commentators. In: M.L. Gill, P. Pellegrin (eds.), A Companion to Ancient Philosophy. (Blackwell Companions to Philosophy) Malden (MA), pp. 597-622.

Innes, D. C. and Winterbottom, M. (1988). Sopatros the Rhetor. Studies on the text of the

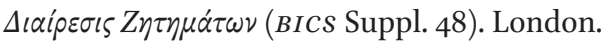

Irigoin, J. (1986). La tradition des rhéteurs grecs dans l'Italie byzantine ( $\mathrm{X}^{\mathrm{e}}-\mathrm{XII}{ }^{\mathrm{e}}$ siècle). Siculorum Gymnasium n.s. 39, pp. 73-82 [= La traditions des textes grecs. Pour une critique historique, Paris 2003, pp. 581-592]. 
Kennedy, G. A. (1983). Greek Rhetoric Under Christian Emperors. Princeton.

Kennedy, G. A. (1994). A New History of Classical Rhetoric. Princeton.

Kowalski, G. (1939a). Ad Georgii Moni in Hermogenis Status commentarii capita scholiis $\mathrm{P}$ adjecta adnotationes criticae. Eos 40, pp. 49-69.

Kowalski, G. (1939b). Commentarium codicis Vaticani gr. 107 in Hermogenis $\pi \varepsilon p i \sigma \tau \alpha ́ \sigma \varepsilon \omega \nu$

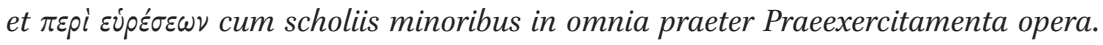
Lwów.

Kowalski, G. (1940-1947). De commentarii in Hermogenis Status e tribus interpretibus confecti (Rh. Gr. IV Walz) recensione in codice Par. Gr. 2923 obvia. Eos 41, 1940-1946, pp. 46-80; 42, 1947, pp. 122-141.

Lamberz, E. (1987). Proklos und die Form des philosophischen Kommentars. In: J. Pépin, H. D. Saffrey (édd.), Proclus, lecteur et interprète des anciens, Actes du colloque international du CNRS, Paris, 2-4 octobre 1985, Paris, pp. 1-20.

Lenz, F. W. (1959). The Aristeides Prolegomena. Leiden.

Lossau, M.J. (1964). Untersuchungen zur antiken Demosthenexegese (Palingenesia Band II). Bad Homburg-Berlin-Zürich.

Maggiorini, D. (2012). Sopatro. Demostene e la corona di Alessandro (Diairesis zetematon, viii.205.5-220.10 Walz), (Hellenica. Testi e strumenti di letteratura greca antica, medievale e umanistica 41). Alessandria.

Mansfeld, J. (1994). Prolegomena: Questions to be Settled before the Study of an Author, or a Text. Leiden.

Most, G. W., ed. (1999). Commentaries - Kommentare. Aporemata: Kritische Studien zur Philologiegeschichte, Band 4. Göttingen.

Nünlist, R. (2009). The Ancient Critic at Work: Terms and Concepts of Literary Criticism in Greek Scholia, Cambridge.

Oomen, G. (1926). De Zosimo Ascalonita atque Marcellino. Münster.

Patillon, M. (2008). Corpus rhetoricum. Préambule à la rhétorique, Anonyme; Progymnasmata, Aphthonios. En annexe:Progymnasmata, Pseudo-Hermogène. Paris.

Patillon, M. (2009). Corpus rhetoricum. Tome II. Hermogène, les états de cause. Paris.

Patillon, M. (2012a). Corpus rhetoricum. Tome III, partie 1-2. Pseudo-Hermogène, L'Invention. Anonyme, Synopse des Exordes. Anonyme, Scolies au traité Sur l'Invention du Pseudo-Hermogène. Paris.

Patillon, M. (2012b). Corpus rhetoricum. Tome IV. Prolégomènes au De ideis - Hermogene, Les catégories stylistiques du discours (De ideis). Paris.

Patillon, M. (2014). Corpus rhetoricum. Tome v. Pseudo-Hermogène, La méthode de l'habileté. Maxime, Les objections irréfutables. Anonyme, Méthode des discours d'adresse. Paris.

Pepe, C. (2013). The Genres of Rhetorical Speeches in Greek and Roman Antiquity. Boston-Leiden. 
Pernot, L. (1989). Aquila. In: R. Goulet (ed.), Dictionnaire des philosophes antiques, vol. I. Paris, pp. 317-321.

Petrucci, F. M. (2017). Wie man eine Platonstelle deutet: Exegetische Strukturen im Mittelplatonismus. Philologus 162/1, pp. 55-91.

Puech, B. (2002). Orateurs et sophistes grecs dans les inscriptions d'époque impériale. Paris.

PS - Prolegomenon Sylloge. Accedit Maximi libellus De obiectionibus insolubilibus, ed. H. Rabe (Rhetores Graeci 14), Leipzig 1931.

Rabe, H. (1892-1893). Syriani in Hermogenem commentaria, 2 voll. Leipzig.

Rabe, H. (1895). De Christophori commentario in Hermogenis librum. RhM 50, pp. 241-249.

Rabe, H. (1899). Ein Phoibammon-Fragment. RhM 54, pp. 632-633.

Rabe, H. (1908a). Aus Rhetoren-Handschriften: 5. Des Diakonen und Logotheten

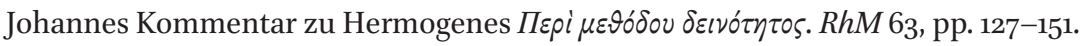

Rabe, H. (19o8b). Aus Rhetoren Handschriften: 7. Georgios. RhM 63, pp. 517-526.

Rabe, H. (1908c). Aus Rhetoren Handschriften: 8. Konstantin Laskaris und der Christophoros Kommentar. RhM 63, pp. 526-530.

Rabe, H. (1909). Aus Rhetoren Handschriften: 10. Einleitungen. RhM 64, pp. 539-590.

Rabe, H. (1913). Hermogenis Opera (Rhetores Graeci 6). Stuttgart.

Rabe, H. (1926). Aphtonii Progymnasmata (Rhetores Graeci 10). Leipzig.

Rabe, H. (1928). Ioannis Sardiani Commentarium in Aphthonii Progymnasmata. Leipzig. $R h G$ - Rhetores graeci, ed. C. Walz, 9 voll., Stuttgart-Tübingen, $183^{2-18} 36$.

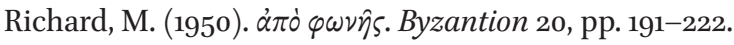

Rogers, J. M. (2017). Didymus the Blind and the Alexandrian Christian Reception of Philo. Atlanta.

Romano, F. (1994). La scuola filosofica e il commento. In: G. Cambiano, L. Canfora e D. Lanza (edd.), Lo spazio letterario della Grecia antica. vol. I. La produzione e la circolazione del testo, t. III, I Greci e Roma. Roma, pp. 587-601.

Romano, R. (1989). Il commentario a Ermogene attribuito a S. Nilo di Rossano. In: Atti del Congresso Internazionale su S. Nilo di Rossano (8 settembre-1 ottobre 1986). Rossano-Grottaferrata, pp. 329-339.

Romano, R. (2007). La teoria retorica a Bisanzio dal tardoantico alla rinascenza macedone. Porphyra 9, pp. 107-125.

Russell, D. A. (1981). Criticism in Antiquity. Berkeley-Los Angeles.

Russell, D. A. and Wilson, N. G. (1979). Menander Rhetor. Edited with Translation and Commentary. Oxford.

Schenkeveld, D. M. (1991). The philosopher Aquila. CQ 41, pp. 490-495.

Schilling, L. (1903). Quaestiones Rhetoricae Selectae. Leipzig.

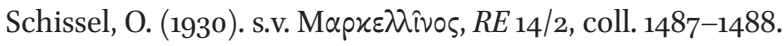

Sluiter, I. (1999). Commentaries and the Didactic Tradition. In: Most 1999, pp. 173-205. 
Smith, A. (1993). Porphyrius. Fragmenta. Stuttgart-Leipzig.

Sorabji, R. R. K., ed. (1990). Aristotle Transformed. The Ancient Commentators and their Influence. London.

Sorabji, R. R. K. (1990a). The Ancient Commentators on Aristotle. In: Sorabji 1990, pp. 1-30.

Stegemann, W. (1941). 'Phoibammon (5)', RE 20/1, coll. 326-343 e 1306.

Stok, F. (2018). Schemi di accessus a Virgilio. Incontri di Filologia Classica 16. Trieste, pp. 229-243.

Szabat, E. (2015). Late Antiquity and the Transmission of Educational Ideals and Methods: The Greek World. In: W. M. Bloomer (ed.), A Companion to Ancient Education, Malden (MA), pp. 252-266.

Ucciardello, G. (2012). Hypomnemata papiracei e lessicografia. Tra Alessandria e Bisanzio. Messina.

Valiavitcharska, V. (2013). Rhetoric and Rhythm in Byzantium: The Sound of Persuasion. Cambridge-New York.

van Berchem, D. (1952). Poètes et grammairiens. Recherche sur la tradition scolaire d'explication des auteurs. $M H$ 9, pp. 79-87.

Ward, J. O. (1995). Ciceronian rhetoric in treatise, scholion and commentary. Turhnout.

Watts, E. J. (2008). City and School in Late Antique Athens and Alexandria (First paperback printing, originally published 2006). (The Transformation of the Classical Heritage, 41). Berkeley-London. 